\title{
Pan Gnammas (Weathering Pits) across Australia: Morphology in Response to Formative Processes
}

\author{
Brian V. Timms \\ Centre for Ecosystem Science, School of Biology, Earth and Environmental Sciences, University of New South Wales, Sydney, \\ Australia \\ Email: brian.timms@unsw.edu.au
}

How to cite this paper: Timms, B.V. (2021) Pan Gnammas (Weathering Pits) across Australia: Morphology in Response to Formative Processes. International Journal of Geosciences, 12, 984-993. https://doi.org/10.4236/ijg.2021.1210051

Received: July 27, 2021

Accepted: October 24, 2021

Published: October 27, 202

Copyright $\odot 2021$ by author(s) and Scientific Research Publishing Inc. This work is licensed under the Creative Commons Attribution International License (CC BY 4.0).

http://creativecommons.org/licenses/by/4.0/

(c) (i) Open Access

\begin{abstract}
Pan gnammas occur across Australia, mainly in granites and sandstones. Their morphology and origins on Eyre Peninsula, South Australia are known, but this Twidale model is not applicable everywhere. I investigated their morphology and theorized on their origins at eight sites across the continent, noting particularly their edge profiles, floors and depths in relation to their geological placement. The steep sides, flat floors, depths up to about $25 \mathrm{~cm}$ in laminated granites apply only in the hot climates of Western Australia and South Australia. Laminations are rare in Victorian granites, so their pan gnammas have sloped edges and are not as deep $(\mathrm{ca} .10 \mathrm{~cm})$ and in the granitic uplands of southeast Queensland, corrosion at the edge is concentrated to a narrow zone and most gnammas are only ca. $5 \mathrm{~cm}$ deep. Gnammas in horizontal sandstones in New South Wales and Queensland have steep or sloping edges and reach $\mathrm{ca} 10 \mathrm{~cm}$ deep but in dipping sandstones of the Grampians, Victoria horizontality of corrosion has produced visors at pan edges. The vertically bedded Uluru sandstones have enabled deeper corrosion and pans of different morphology. Regional depth variation has biological consequences.
\end{abstract}

\section{Keywords}

Corrosion, Water Layer Weathering, Laminations, Visors

\section{Introduction}

Though gnammas (weathering pits/rock holes) have been recognized worldwide for about 200 years [1] [2] [3], a scientific explanation for their distinctive morphology and origins was first provided by Twidale and Corbin [4] for examples 
on granite outcrops on Eyre Peninsula, South Australia. Further details were added by [5] and [6], partly based on wider experience of gnammas in southern WA and also by some detailed maps of [7]. In essence, their formation is due to chemical attack, mainly by carbonic acid, at the pan edge at the air-water-rock interface, facilitated by penetration into the lamination planes. The laminations are formed by expansion and rupture of the near surface of granitic rock on extremely hot days. Chemical attack also occurs on the floor of the gnamma when water levels are low, which maintains the horizontality of the floor. This model is implied for gnammas worldwide e.g. [8] and for examples across Australia [9], but reality variations in geology and formative processes produce pan gnammas of various forms. Such gnammas should not be confused with pit gnammas, which are much deeper (ca $0.5-1.5 \mathrm{~m}$ ) and narrower and formed by different dominant processes [10].

However, while corrosion is the central formative process and petri dish shaped hollows result, details vary according to many factors particularly climate and geology. In Australia laminations in granite mainly occur in the hot summer climates of Western Australia and South Australia, while the colder climate and less regular rainfall of the Granite Belt in southeast Queensland provide a different corrosive environment. Furthermore granitic and arenaceous rocks probably corrode differently to produce gnammas of different form.

It is my aim in this paper to explore variations in gnamma formative processes and morphology, by examining a number of pan gnammas across Australia. Besides understanding that there are variations in processes and morphology, I hope that studies on weathering pits/rock holes elsewhere in the world take cognizance of these possibilites.

\section{Study Sites and Methods}

My research into pan gnamma geomorphology aims to relate form to processes which I think are operating. Morphology is determined by detailed mapping as exemplified at one typical gnamma in dipping sandstone in the Grampians, Victoria and also to a limited degree of just the edges of the Queensland gnammas in granite. Some information can be gained by superficial examination of other gnammas, often in remote places difficult to access.

1) Grampians, Victoria

Much of the Grampians in eastern Victoria is made of quartzose sandstones, and although they are tilted in many places at about $20^{\circ}$, pan gnammas are common, especially in the Red Man Bluff Subgroup rocks at the northern end. Of about 12 large gnammas at Flat Rock $\left(36^{\circ} 53^{\prime} \mathrm{S}, 142^{\circ} 22^{\prime} \mathrm{E}\right)$, one was mapped with a dumpy level when dry on March 12, 2021. The more advanced method of using a drone [11] was not permitted locally. Firstly, a $20 \mathrm{~cm}$ interval grid of long solid rods clamped together where they crossed at right angles was established, and depths were determined at grid intersections, and sometimes at 10 $\mathrm{cm}$ intervals, with a staff at an accuracy of $\pm 0.5 \mathrm{~cm}$. A contour map was then 
drawn from known depths marked on graph paper. Gnamma edges were difficult to map and a short, hand-held ruler had to be employed under the overhanging visors. Full water level was easily determined by stains on the rock, supported by the lack of lichens. This level was designated the $0 \mathrm{~cm}$ contour and other contours at appropriate depths were drawn. Morphometric parameters such as area, volume, shoreline development and volume development were calculated following the methods in [12].

2) Other sites

Gnammas in granite at Greenlands via Stanthorpe, Queensland $\left(28^{\circ} 37^{\prime} 55^{\prime \prime S}\right.$, $\left.151^{\circ} 48^{\prime} 48^{\prime \prime} \mathrm{E}\right)$ were revisited, to detail heights and horizontal incisions at their edges, thus adding to existing maps and data [11].

Gnammas in arenaceous rocks at Bundeena, NSW (34 $\left.05^{\prime} 52^{\prime \prime} \mathrm{S}, 151^{\circ} 99^{\prime} 41^{\prime \prime} \mathrm{E}\right)$, Cobbald George, via Forsyth, Queensland ( $\left.18^{\circ} 49^{\prime} 01^{\prime \prime S}, 151^{\circ} 09^{\prime} 41^{\prime \prime E}\right)$ and Uluru, Northern Territory $\left(25^{\circ} 20^{\prime} 41^{\prime \prime} \mathrm{S}, 131^{\circ} 01^{\prime} 56^{\prime \prime} \mathrm{E}\right)$ were visited to gain preliminary data on their structure.

The locations of these sites and of studied sites on granite in Western Australia and South Australia are depicted in Figure 1.

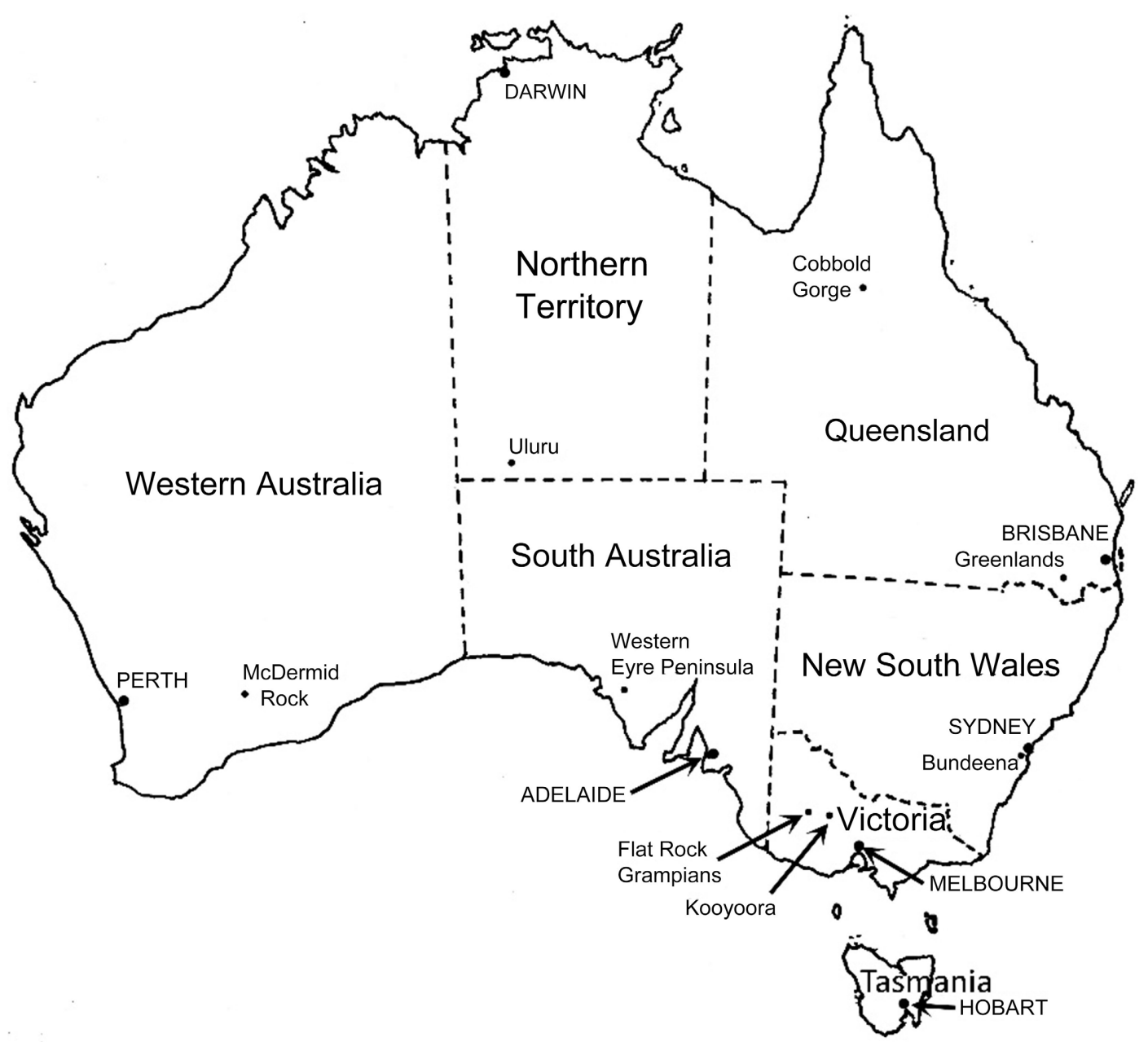

Figure 1. Map of Australia showing location of the gnammas mentioned in the text. 


\section{Results}

All except one of the gnammas at Flat Rock in the Grampians are flat floored with steep edges, relatively shallow $(6-22 \mathrm{~cm}$ ), but bigger than average (longest axis 230 to $830 \mathrm{~cm}$ ). Although near the summit of Flat Rock, all are located in dipping quartzose sandstones. Most of their edges are undercut, particularly on the upslope of the dip, resulting in pronounced visors in some cases. On the mapped gnamma, the sloping visors above the lower edge are up to $15 \mathrm{~cm}$ wide (Figure 2, Figure 3). Upslope visors (on the left in Figure 2) are broadly triangular in section with a smooth surface below and rough surface above at approximately the dip of the rock. Downslope visors (on the right in Figure 2) are less developed, with a similar smooth surface below, but of variable slope and texture above.

The mapped gnamma has an area of $3.7 \mathrm{~m}^{2}$, volume of $660 \mathrm{Ml}$, maximum depth of $22 \mathrm{~cm}$, shoreline length of $7.5 \mathrm{~m}$, shoreline development of 1.1 and volume development of 2.47. Shoreline development is a measure of the degree of irregularity of the shoreline. Essentially it is the ratio of the length of the shoreline to the length of the circumference of a circle of area equal to that of the pond [12]. Volume development expresses the form of the pond; values near one suggest a cone shape and at the other extreme values near three are typical of flat floored, steep sided ponds [12].

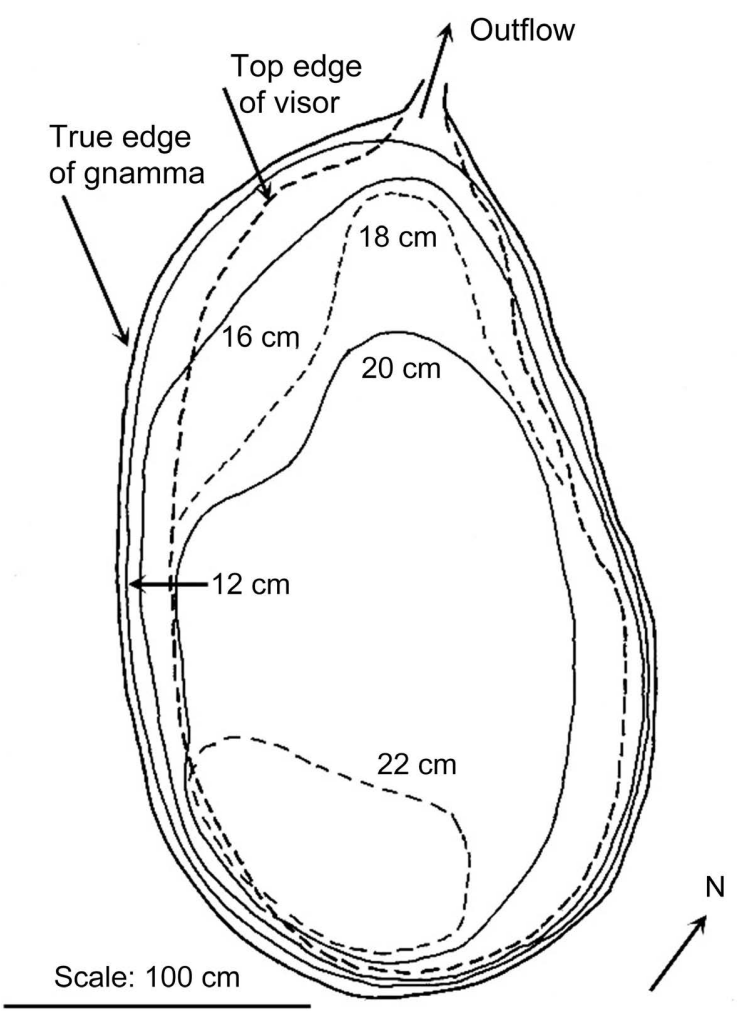

Figure 2. Map of a gnamma on Flat Rock, Grampians, Victoria. Note while all contours are horizontal, the line marking the edge of the visor varies vertically with the edge of the visor. 


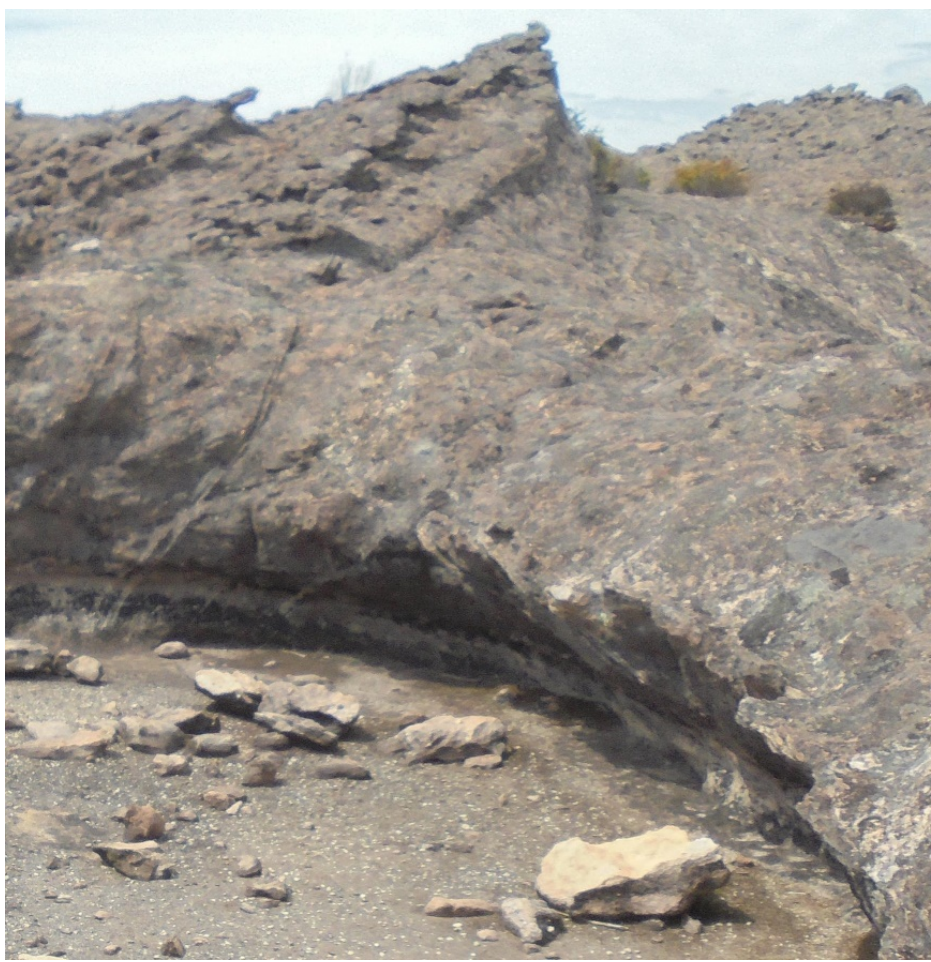

Figure 3. Undercut edge to form a visor in the mapped gnamma on Flat Rock.

Gnammas at Greenlands in the mountains of southeast Queensland have small undercut $\mathrm{C}$-shaped edges that are generally asymmetrical, with the greatest indent near the base (at about $1-1.5 \mathrm{~cm}$ ), and usually $4-5 \mathrm{~cm}$ high (Figure 4(b)). Often, there is a less distinct C-shaped section above the basal C edge, and sometimes an even less distinct indication above this, all interpreted as previous shorelines prior to the overflow being lowered by erosion (Figure 4(a)).

Gnammas on arenaceous rocks as at Bundeena (Figure 5(a)) and Cobbold Gorge (Figure 5(b)), both in horizontally bedded sandstones, are about 8 - 10 $\mathrm{cm}$ deep and have smooth near vertical edges and flat floors. In contrast, gnammas on Uluru are much deeper, often about $30-50 \mathrm{~cm}$, and have steep upper sides but often sloping lower sides (Figure 5(c), Figure 5(d)). The pond floors are flat centrally, often with a thick layer of sediment. More remarkable is that the gnammas are aligned in long parallel lines in the straight, almost vertical bedding plains.

\section{Discussion}

The typical pan gnamma topographies found on western Eyre Peninsula, South Australia, and across the Wheatbelt of Western Australia are depicted in Figures 6(a)-(d). As noted by [5] [6] and [7], such pans have steep edges, often against exposed laminations, and flat floors at about $25 \mathrm{~cm}$ depth. The above authors attribute their formation to chemical attack, mainly by carbonic acid, at the pan edge at the air-water-rock interface, facilitated by penetration into the lamination planes. The laminations are formed by expansion and rupture of the near 
(A)

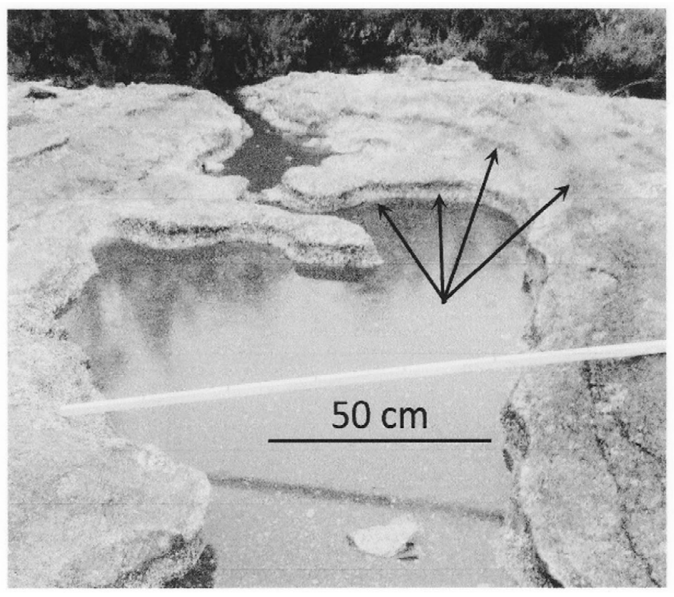

(B)

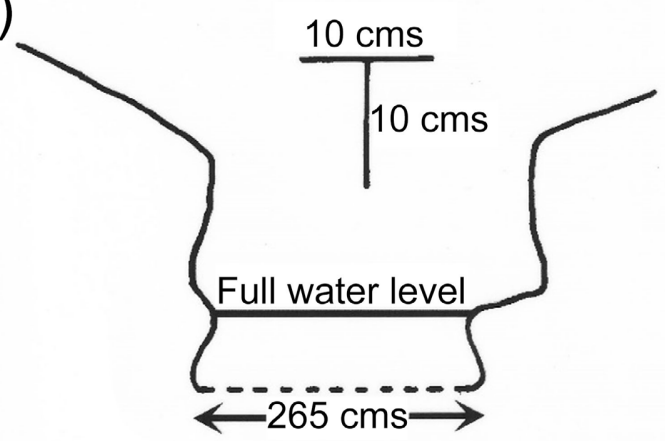

Figure 4. Two gnammas at Egernia, Greenlands, Queensland. (A) A gnamma with arrows pointing to present water level and three former zones of corrosion above it, (B) detailed diagram of another gnamma showing corrosion zone below water level and an old one above it.
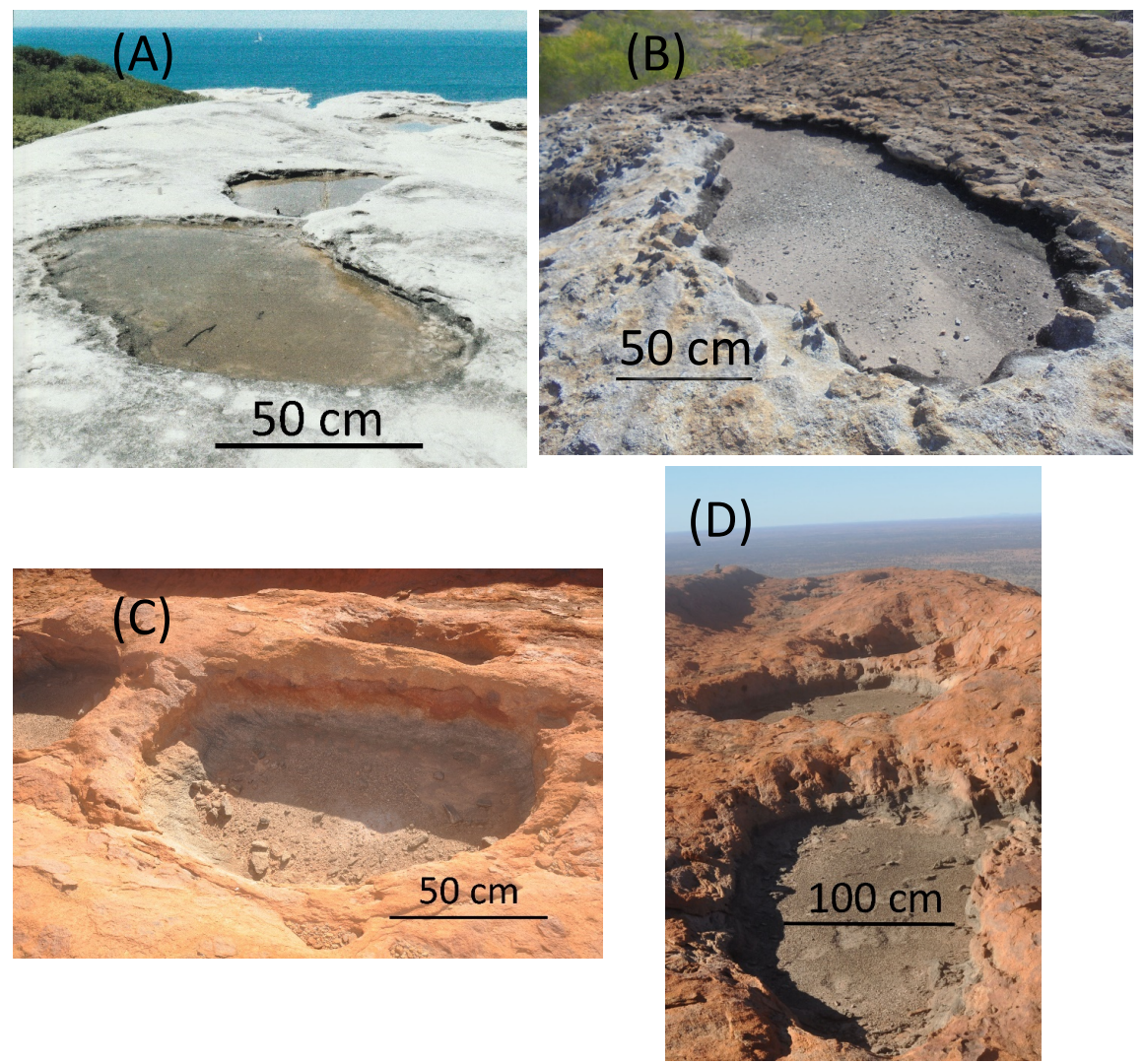

Figure 5. Gnammas in sandstone. (A) A gnamma on the oceanic clifftop near Bundeena, New South Wales. (B) A gnamma at Cobbold Gorge, via Forsyth, Queensland, (C) and (D) two gnammas on top of Uluru, Northern Territory.

surface of granitic rock on extremely hot days. Chemical attack also occurs on the floor of the gnamma when water levels are low, which maintains the horizontality of the floor. Some pan gnammas are incised into the rock and deeper than $20 \mathrm{~cm}$ (Figure 6(d)), though usually a water filling is only a few centimeters 

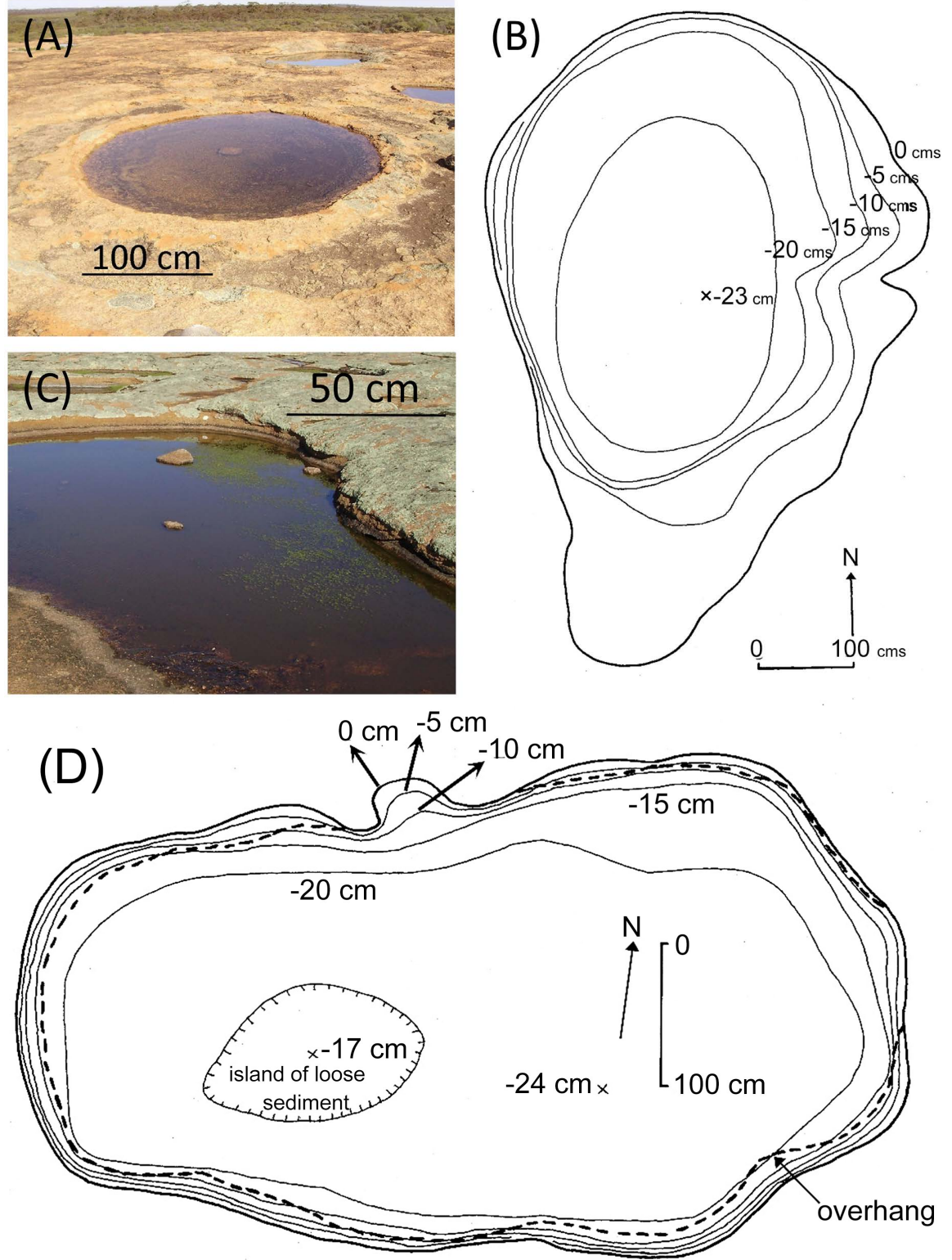

Figure 6. Deeper gnammas on granite. (A) Example on McDermid Rock, Western Australia, (B) example on Polda Rock with laminations visible, South Australia, (C) map of one on Polda Rock, South Australia, (D) map of an incised gnamma, Pildappa Rock, South Australia. (C) and (D) modified from [13].

deep. In these cases, further lowering of the floor occurs through water layer weathering [5] [7]. Also, in areas with a nearby salt source (the ocean or salinas), the chemical attack is aided by salt crystallation, leading to steeper edges and a deeper pan [7].

The pan gnammas in the Grampians in western Victoria are similar, but the edges are more undercut (Figure 2, Figure 3). As a pan grows laterally, the horizontality is maintained, despite the dipping rock strata. This is because corrosion occurs in a narrow band at the horizontal water-air-rock interface, whatever the depth of water, corroding the floor mainly horizontally by also downwards 
across the entire pan. The arenaceous rock is probably a little more corrodible than granites, so expansion of the floor is easier despite etching into rock half a meter or more thick. Consequently, a remnant visor is formed, thick at its base and narrowing, often uniformly, to a thin edge well above high water level (Figure 3).

Morphometrically, the mapped pan at Flat Rock is similar to the two mapped pan gnammas on Eyre Peninsula [7]. They are two to three meters wide and about $20 \mathrm{~cm}$ deep and characteristically have shoreline developments just above one, indicating a round-oval shape, and volume developments near three, as expected in a flat-floored lake with steep sides [12].

In central Victoria at Kooyoora, granite outcrops are small and surrounded by forests. Their pan gnammas are small (1 - $2 \mathrm{~m}$ wide) and shallow $(6-12 \mathrm{~cm}$ deep) [9]. The edges are generally smooth and often at a low angle. These exposed granites in Victoria rarely have surface laminations, supposedly due to the nearby forests protecting them from extreme heat. So, they tend to be shallower than Eyre Peninsula gnammas (with a mean depth of $10.1 \mathrm{~cm}$ [9] compared to $18.1 \mathrm{~cm}$ at Polda, Eyre Peninsula [13]), which has hydrological and biological consequences [13].

Most Stanthorpe gnammas are shallow ( $<6 \mathrm{~cm}$ deep) due to edge corrosion being restricted to a narrow vertical zone, as is evident in the Greenlands gnammas (Figure 4). Why this should be is not entirely clear, though their altitude (ca $1000 \mathrm{~m}$ asl) and forested locations mean they are cooler than gnammas elsewhere, so chemical corrosion is probably slower. Also, rainfall is irregular, evaporation is low and there are few very hot days to laminate the granite, all resulting in less vigorous chemical attack. The shallow depths are largely responsible for lower invertebrate diversity in these gnammas [11].

At the few sites inspected in horizontally bedded sandstones (Figure 5(a), Figure 5(b)) the edges are apparently being corroded, resulting in fairly smooth vertical faces, and the flat floors are apparently subject to water table leveling. Laminations are rare in these sites, so most gnammas are shallow (up to about $10 \mathrm{~cm}$ deep). Again, such pond depths are not conducive to high invertebrate diversity. The communities in the one area studied biologically are not diverse, but more study is needed to verify this at a broader scale [14].

The gnammas on top of Uluru are different from most gnammas in arenaceous sediments, not only in their geomorphology but in their evolution. The lithology is unique, being coarse grained with significant felspar content and lying in vertically bedded sedimentary arkose sandstones. Walls are typically coated with hematite-geothite [15] and some lamination is evident [5]. The gnamma floors are probably lowered by a combination of water-layer weathering (maintaining horizontality) and corrosion attack along any laminations [5] [15] and also possibly by processes of weathering along a deep hemispherical front as in pit gnammas [16]. What seems clear is the role of vertical bedding planes in promoting corrosion, given the position of the gnammas in rows along bedding 
planes, which probably permits greater penetration of water. Exactly what processes form these unique gnammas is delayed because the present closure of the climb to Uluru's summit prevents further study.

\section{Conclusion}

Clearly the pan gnammas studied across Australia have a commonality of process and form and it is likely that this applies worldwide. Surface laminations enable gnammas to be deeper than in most other situations because of deeper access for corrasion, but in most granite and all arenaceous sediments, laminations are not common. Hence the Twidale model is far from universal applicability. But edge corrosion at the air-water-rock interface is universal, as water layer weathering, again by corrosion when water is shallow. These processes also occur in arenaceous rocks but details are lacking. What is known however is keeping horizontality of the pan floor is paramount, meaning visors are formed at the edge in dipping rocks. The characteristic depths of the various gnammas have biological consequences.

\section{Acknowledgements}

I thank Phil Coleman who helped me map the gnamma on Flat Rock, to Carol Booth and Tim Low for access to their property at Greenlands, to Jonathon Christian for permission to use his photographs of Uluru gnammas, and to Carol Booth, Phil Coleman and Joan Powling for comments on a draft manuscript.

\section{Support}

This study was done during retirement and relied entirely on self funding.

\section{Conflicts of Interest}

There were no conflicts of interest in this research or the writing of this paper.

\section{References}

[1] Matthes, P.E. (1930) Geologic History of the Yosemite Valley. Professional Paper 160, United States Geological Survey, Reston, 137 p. https://doi.org/10.3133/pp160

[2] MacCulloch, J. (1814) On the Granite Tors of Cornwall. Transactions of the Geological Society of London, 2, 66-78. https://doi.org/10.1144/transgsla.2.66

[3] Smith, L.L. (1941) Weather Pits in Granite of the Southern Piedmont. Journal of Geomorphology, 4, 117-127.

[4] Twidale, C.R. and Corbin, E.M. (1963) Gnammas. Revue de Géomorphologie Dynamique, 14, 1-20.

[5] Twidale, C.R. and Bourne, J.A. (1976) Origin and Significance of Pitting on Granitic Rocks. Zeitschrift für Geomorphologie, 20, 405-416.

[6] Twidale C.R. and Bourne, J.A. (2012) Contrasted Perceptions of Uluru. Physical Geography, 33, 285-302. https://doi.org/10.2747/0272-3646.33.3.285

[7] Timms, B.V. and Rankin, C. (2015) The Geomorphology of Gnammas (Weathering pits) of Northwestern Eyre Peninsula, South Australia: Typology, Influence of Ha- 
loclasty and Origins. Transactions of the Royal Society of South Australia, 140, 28-45. https://doi.org/10.1080/03721426.2015.1115459

[8] Brendonck, L., Lanfranco, S, Timms, B.V. and Vanschoenwinkel, B. (2016) Invertebrates in Rock Pools. In: Batzer, D. and Boix, D., Eds., Invertebrates in Freshwater Wetlands, Springer, Cham, 25-53. https://doi.org/10.1007/978-3-319-24978-0 2

[9] Timms, B.V. (2017) A Study of the Gnammas (Rock Pools) in Some Granitic Outcrops in Central Victoria, with a Comparison of Their Invertebrate Communities across Southern Australia. The Royal Society of Victoria, 129, 21-36. https://doi.org/10.1071/RS17002

[10] Timms, B.V. (2013) Geomorphology of Pit Gnammas in Western Australia. Journal Royal Society of Western Australia, 96, 7-16.

[11] Timms, B.V., Booth, C, Newman, M and McCann, J. (2020) The Ecology of Gnammas (Weathering Pits) on the Stanthorpe Plateau, Northern New England Tablelands, with Special Reference to the Clam Shrimp Paralimnadia urukhai (Webb and Bell)(Crustacea: Branchiopda: Spinicaudata). Proceedings of the Royal Society of Queensland, 124, 7-28.

[12] Timms, B.V. (1992) Lake Geomorphology. Gleneagles Press, Adelaide.

[13] Timms, B.V. (2014) Community Ecology of Aquatic Invertebrates in Gnammas (Rock Holes) if North-Western Eyre Peninsula, South Australia. Transactions of the Royal Society of South Australia, 138, 147-160. https://doi.org/10.1080/03721426.2014.11649006

[14] Bishop, J.A. (1974) The Fauna of Temporary Rain Pools in Eastern New South Wales. Hydrobiologia, 44, 319-323. https://doi.org/10.1007/BF00187280

[15] Twidale C.R. and Bourne, J. A. (2018) Rock Basins (Gnammas) Revisted. Géomorphologie: Relief, Processes, Environment, 2492, 139-147.

[16] Twidale, C.R. (1971) Structural Landforms. ANU Press, Canberra. 